\title{
Surface functionalization determines behavior of nanoplastic solutions in model aquatic environments
}

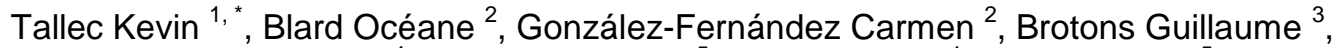 \\ Berchel Mathieu ${ }^{4}$, Soudant Philippe ${ }^{5}$, Huvet Arnaud ${ }^{1}$, Paul-Pont Ika ${ }^{5}$
}

${ }^{1}$ Ifremer, Laboratoire des Sciences de l'Environnement Marin (LEMAR), UMR 6539

UBO/CNRS/IRD/Ifremer, CS 10070, 29280, Plouzané, France

${ }^{2}$ Laboratoire des Sciences de l'Environnement Marin (LEMAR), UMR 6539 CNRS/UBO/IRD/Ifremer, Institut Universitaire Européen de la Mer, Technopôle Brest-Iroise, Rue Dumont d'Urville, 29280,

Plouzané, France

${ }^{3}$ Institut des Molécules et Matériaux du Mans, UMR CNRS 6283, Le Mans Université, 72085, Le Mans, France

${ }^{4}$ Université de Brest, Université Européenne de Bretagne, CNRS UMR 6521, CEMCA, IFR 148

ScInBios, 6 Avenue Victor Le Gorgeu, 29238, Brest, France

*Corresponding author : Kevin Tallec, email address : kevin.tallec@univ-brest.fr

\begin{abstract}
:
Plastic debris are classified as a function of their size and recently a new class was proposed, the nanoplastics. Nano-sized plastics have a much greater surface area to volume ratio than larger particles, which increases their reactivity in aquatic environment, making them potentially more toxic. Only little information is available about their behavior whereas it crucially influences their toxicity. Here, we used dynamic light scattering (DLS) to explore the influence of environmental factors (fresh- and saltwater, dissolved organic matter) on the behavior (surface charge and aggregation state) of three different nano-polystyrene beads $(50 \mathrm{~nm})$, with (i) no surface functionalization (plain), (ii) a carboxylic or (iii) an amine functionalization. Overall, the positive amine particles were very mildly affected by changes in environmental factors with no effect of the salinity gradient (from 0 to $653 \mathrm{mM}$ ) and of a range $1-30 \mu \mathrm{g} . \mathrm{L}-1$ and $1-10 \mu \mathrm{g} . \mathrm{L}-1$ of organic matter in artificial seawater and ultrapure water, respectively. These observations are supposedly linked to a coating specificity leading to repulsive mechanisms. In contrast, the stability of the negatively charged carboxylic and plain nanobeads was lost under an increasing ionic strength, resulting in homo-aggregation (up to $10 \mu \mathrm{m}$ ). The increase in organic matter content had negligible effect on these two nanobeads. Analysis performed over several days demonstrated that nanoplastics formed evolving dynamic structures detected mainly with an increase of the homo-aggregation level. Thus, surface properties of given polymers/particles are expected to influence their fate in complex and dynamic aquatic environments.
\end{abstract}




\section{Highlights}

- The behavior of different nanopolystyrene beads was investigated by dynamic light scattering. Surface functionalization affects the behavior of nanopolystyrene beads. Carboxylate and plain nanopolystyrene beads formed microscale aggregates in seawater. Organic matter had negligible effect on all nanoplastics tested. Nanoplastics formed evolving dynamic structure over time.

Keywords : Nanoplastic, Dynamic light scattering, Behavior, Aggregation, Salinity, Organic matter 
39 Owing to the exponential use of plastic items (335 million tons (MT) produced in 2016) by human

40 societies, their mismanagement after usage is a considerable problem of this century (Galloway et 41 al., 2017; PlasticsEurope, 2017). Every year, among the 31.9 MT of plastic wastes that are discarded in environment, between 4.8 and 12.7 MT end up in oceans (Jambeck et al., 2015; Rochman, 2018).

43 To date, plastic debris are ubiquitous in freshwater and marine systems from rivers to oceans (Cózar 44 et al., 2014, 2017; Lebreton et al., 2017; Woodall et al., 2014).

45 For about a decade, the research emphasis is laid on the small plastic debris called "microplastics $46(\mathrm{MP} ;<1 \mathrm{~mm})$ " originating from manufactured beads/pellets/fibers or mostly (> 80\%) the weathering of bigger wastes under environmental conditions (UV light, mechanical degradation, biodegradation) (Hüffer et al., 2017; Galloway et al., 2017). However, a new class of smaller debris than MP was proposed lately, the nanoplastics (NP) (Koelmans et al., 2015) which their first report was argued in the North Atlantic Gyre (Ter Halle et al., 2017). To date, several classifications of NP

51 were proposed : $<20 \mu \mathrm{m}$ according to the size used to classify nanoplankton (Wagner et al., 2014);

$52<1 \mu \mathrm{m}$ owing to the colloidal nature of NP (Gigault et al., 2018); $<100 \mathrm{~nm}$ in the narrower sense of 53 the definition of engineered nanomaterials (Mattsson et al., 2015). This last classification is the one 54 adopted for this present study. Similarly to MP, NP in the oceans can originate from a direct release 55 from cosmetics (Hernandez et al., 2017), industrial activities (Dubey et al., 2015; Stephens et al., 56 2013; Zhang et al., 2012), drugs (Lusher et al., 2017); or from weathering of bigger waste as it was 57 demonstrated in laboratory under biotic (Dawson et al., 2018) or abiotic conditions (Gigault et al., 2016; Lambert and Wagner, 2016). 
59 Nanoplastics are known to have a higher surface area/volume ratio than MP. Thus, increasing

60 interactions with persistent organic pollutants (POP) (Liu et al., 2018; Velzeboer et al., 2014) and

61 biological membranes (Rossi et al., 2014) calling for an accurate description of NP in the context of

62 the chemical/biological risks in aquatic systems (Koelmans et al., 2016; Paul-Pont et al., 2018).

63 Although ecotoxicological studies reported higher detrimental effects of NP than MP (e.g. Jeong et

64 al., 2016; Tallec et al., 2018), the behavior of NP (e.g. interactions of NP amongst themselves and

65 other component such as organisms and macromolecules) in experimental environments and even

66 more in freshwater and marine environments remains largely unknown. However, because the

67 behavior drives fate and toxicity of nanoparticles (Lowry et al., 2012), it is crucial to fill the gaps

68 limiting our knowledge in order to understand the toxicity for aquatic life (e.g. Paul-Pont et al.,

69 2018), risks for the balance of ecosystems (Galloway et al., 2017; Mattsson et al., 2015) and up to

70 human health (Wright and Kelly, 2017). Based on works from other nanomaterials, the behavior of

71 NP may be driven by three main processes: physical transformations (homo- or hetero-

72 aggregation); biological transformations (interaction with all components of a biological system

73 involving oxidation and redox mechanism transforming the surface layer of particle); interaction

74 with macromolecules (e.g. adsorption of polysaccharide, organic matter, protein) leading to the

75 development of bio- (in organism) or eco-coronas (in environment) (Galloway et al., 2017; Lowry et

76 al., 2012; Mattsson et al., 2015).

77 A modelling study using various scenarios showed that NP aggregation in freshwater system could

78 decrease the risk of NP arrival in the oceans (Besseling et al., 2017). Owing to the high diversity of

79 polymers found in oceans and thus the high diversity of their chemical structures, this model-based

80 assumption must be compared with experimental data and in situ observations when methods will

81 be developed for NP. Indeed, as reported for other nanomaterials, variations of the chemical 
82

surface of the same material affected greatly its behavior in fluids (El Badawy et al., 2010). Also, nanoparticles' behaviors are known to be impacted by environmental factors (e.g. pH, salinity, organic matter content) (Keller et al., 2010). Thus, the behavior of NP may be highly complex and their fate can vary from location to location. Furthermore, from our previous study in which we revealed significant toxicity of NP on oyster fertilization success and embryo-larval development, NP behavior was hypothesized as the origin of the toxicity variability of three different $50 \mathrm{~nm}$ plastic beads (Tallec et al., 2018). During the redaction of this present work, Cai et al. (2018) investigated the short-term influence (600 seconds) of environmental factors on behavior of NP and reported a low incidence of organic matter on the aggregation kinetics of nanopolystyrene (nano-PS) beads (plain; $100 \mathrm{~nm}$ ) in media containing various salt $\left(\mathrm{NaCl}-1-100 \mathrm{mM} ; \mathrm{CaCl}_{2}-0.1-15 \mathrm{mM} ; \mathrm{FeCl}_{3}-\right.$ 0.001-1 mM). However, the size and the surface-functionalization which display an important role in the behavior of particles (Alimi et al., 2018) were not studied and yet of great interest particularly below $100 \mathrm{~nm}$ (Gigault et al., 2018). Here, we performed Dynamic Light Scattering (DLS) analyses with nanopolystyrene $(50 \mathrm{~nm})$ exhibiting different surface functionalization (carboxyl, amine or none) employed in previous ecotoxicological studies including ours (Della Torre et al., 2014; Jeong et al., 2016; Tallec et al., 2018). The influence of several media (ultrapure water, artificial or filtered natural seawater) and environmental factors (salinity and organic matter gradients) was explored with a temporal survey on their behavior in suspension for coping with environmental variability and to anticipate further ecotoxicology testing.

\section{$2 \quad$ Materials and Methods}

\subsection{Nanoplastics}


103 Three types of nanopolystyrene beads $(50 \mathrm{~nm})$ were used in this study: (i) without surface

104 functionalization - PS-Plain; (ii) with carboxyl groups - PS-COOH; (iii) with amine groups - PS- $\mathrm{NH}_{2}$.

105 All NP were purchased from Polysciences/Bangs Laboratories and stored at $4^{\circ} \mathrm{C}$ prior to 106 experiments. Polymer types were previously confirmed by Raman microspectroscopy analysis 107 (Tallec et al., 2018). Commercial suspensions were supplied in ultrapure water (UW) with a small 108 amount of surfactant $\left(<0.1 \%\right.$; Tween- $\left.20^{\circ}\right)$. All tests were performed with the same batch of 109 particles.

\section{$110 \quad 2.2$ Dynamic Light Scattering (DLS) analyses}

111 For DLS analyses, commercial suspensions of NP were diluted in UW at a stock concentration of $1121,000 \mathrm{mg} \cdot \mathrm{L}^{-1}$ then at a work concentration of $100 \mathrm{mg} \cdot \mathrm{L}^{-1}$ in the selected media according to Tallec et 113 al. (2018). It was the optimal concentration allowing high reproducibility and sufficient detection 114 level of particles by DLS. The need to use high particles concentration to reach a high measurement 115 accuracy is common in the field of nanoparticles such as PS (50 mg. $\mathrm{L}^{-1}$; Cai et al., 2018); iron oxide

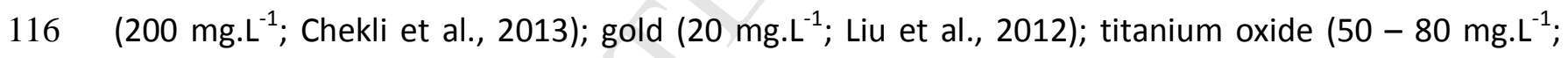
117 French et al., 2009; Loosli et al., 2013) and zinc oxide (100 mg. L $^{-1}$; Mohd Omar et al., 2014). The 118 analysis of colloidal fraction from environmental matrices required ultrafiltration (Mintenig et al., 119 2018). The ultrafiltration factor used by Ter Halle et al. (2017) to detect traces of NP from the North 120 Atlantic Gyre was 200. Therefore the concentration of our working solutions could be extrapolated 121 inversely leading to an environmental value theoretically equivalent to $500 \mu \mathrm{g} \cdot \mathrm{L}^{-1}$.

122 DLS measurements were performed with a nano-Zetasizer ZS (Malvern Instruments, UK) using an 123 angle of $173^{\circ}$ Backscatter, a temperature of $20^{\circ} \mathrm{C}$ and an equilibration of 120 sec (González124 Fernández et al., 2018). We used the implemented data analysis software to measure the mean size 
125 of particles/aggregates (Z-average; $\mathrm{nm}$ ), the aggregation state (polydispersity index - PDI; Arbitrary

126 Units (A.U.)) and the mean surface charge ( $\zeta$-potential; mV) of NP. When the PDI exceeded 0.2,

127 particles were deemed to be aggregated. The accuracy of all measures was verified with the report

128 quality from the implemented software and a counting rate being always higher than $100 \mathrm{kcps}$. The

129 nanoplastic suspensions were injected in disposable fold capillary cells (DTS 1060C, Malvern

130 Instruments, UK) with syringes to obtain a final volume of $1 \mathrm{~mL}$. All measurements were performed

131 in triplicate (13 runs and 10 sec.measure ${ }^{-1}$ for PDI and Z-average; 40 runs and 10 sec.measure ${ }^{-1}$ for $\zeta-$

132 potential) according to González-Fernández et al. (2018). No effect of the surfactant is expected

133 owing to its residual concentration $(<0.0001 \%)$ in all samples (Douglas et al., 1985).

\section{$134 \quad 2.3$ Effects of environmental conditions}

\subsubsection{Influence of media}

136 All particles were tested in three different media: (i) ultrapure water (UW; pH $6.6 \pm 0.2$ ); (ii)

137 artificial seawater (ASW; pH $8.1 \pm 0.1 ; 30$ practical salinity unit [PSU]; $\mathrm{NaCl} 450 \mathrm{mM}, \mathrm{KCl} 10 \mathrm{mM}$,

$138 \mathrm{CaCl}_{2} 9 \mathrm{mM}, \mathrm{MgCl}_{2} 30 \mathrm{mM}$ and $\mathrm{MgSO}_{4} 16 \mathrm{mM}$ ); (iii) 2- $\mu \mathrm{m}$ filtered natural seawater from the Bay of

139 Brest sampled in January 2018 (FSW; pH $8.2 \pm 0.1$; PSU 32).

\section{$140 \quad$ 2.3.2 Influence of the salinity}

141 To investigate the influence of the salinity, UW and ASW were used to create five intermediate 142 solutions according to Loucaide et al. (2008): 0\% (0 PSU; 0 mM), 25\% (7.5 PSU; $163.25 \mathrm{mM}$ ), 50\% 143 (15 PSU; $326.5 \mathrm{mM}$ ), 75\% (22.5 PSU; $489.75 \mathrm{mM}$ ) and 100\% of ASW (30 PSU; $653 \mathrm{mM}$ ). Solutions 144 were made one-day prior experiment and kept in dark condition at $4^{\circ} \mathrm{C}$ until use. 


\subsubsection{Influence of the organic matter}

146 We used humic acid as a proxy of the presence of dissolved organic matter (DOM) in freshwater and

147 estuarine/coastal environments (Baalousha et al., 2008; Cai et al., 2018; Fabrega et al., 2009).

148 Humic acid (OM; CAS 1415-93-6) was purchased from Sigma-Aldrich. A stock solution of 1 g.L ${ }^{-1}$ was

149 prepared in UW or ASW and stirred during 24h then filtered on $0.2 \mu \mathrm{m}$ (aPES membrane) according

150 to Yang et al. (2013). For testing the influence of the OM concentration, work solutions were

151 adjusted at three concentrations $\left(1,10\right.$ and $\left.30 \mathrm{mg} \cdot \mathrm{L}^{-1}\right)$ corresponding to realistic aquatic

152 concentrations (Cai et al., 2018). Measurements were performed immediately after contact (T0).

153 NP behavior was also observed over time in UW and ASW alone and with organic matter (UW+OM 154 and $\mathrm{ASW}+\mathrm{OM})$ at the intermediate concentration $\left(10 \mathrm{mg} \cdot \mathrm{mL}^{-1}\right)$. Measurements were performed at 155 T0, T24h and T48h.

157 Statistical analyses and graphical representations were conducted using the R Software (R Core

158 Team, 2016). Before statistical comparisons, normality and homoscedasticity were screened with

159 the Shapiro-Wilk and Levene's methods, respectively. All analyses were operated using one-way

160 ANOVA followed by pairwise comparisons (Tukey's method) when needed. Effects of treatment on

161 the size average were performed only when the PDI was greater than a threshold set to 0.2

162 indicating the start of an aggregation. The significance threshold was set at a $p$-value $<0.05$. Data 163 are expressed as the mean \pm standard deviation (SD).

\section{Results}

\subsection{Influence of media}


166 The PS- $\mathrm{NH}_{2}$ stayed at a nanometric scale in all media: $53.3 \pm 2.3 \mathrm{~nm}$ in UW, $52.5 \pm 0.5 \mathrm{~nm}$ in ASW

167 and $67.9 \pm 0.8 \mathrm{~nm}$ in FSW (Figure 1A). A small aggregation was observed in FSW (PDI > 0.2; ANOVA,

$168 \mathrm{~F}=110.8, \mathrm{p}$-value $<0.001)$. In contrast, the aggregation level of the PS-COOH and PS-Plain solutions

169 increased significantly (ANOVA; PS-COOH: $F=135.3, p$-value $<0.001$; PS-Plain: $F=358.5, p$-value <

170 0.001) following the same trend between each medium (Figure 1A). Particles stayed at a

171 nanometric scale (PS-COOH; $63.4 \pm 3.43 \mathrm{~nm}$; PS-Plain: $56.0 \pm 0.2 \mathrm{~nm}$; PDI < 0.2) only in UW and

172 formed microscale aggregates in ASW (PS-COOH: 1,835.0 $\pm 240.0 \mathrm{~nm}$; PS-Plain: 2,106.7 $\pm 75.4 \mathrm{~nm}$ )

173 and FSW (PS-COOH: 4,530.3 $\pm 528.0 \mathrm{~nm}$; PS-Plain: 4,810.3 $\pm 370.2 \mathrm{~nm}$ ).

174 The $\zeta$-potential of all particles was significantly different between UW and seawater (ANOVA; PS-

$175 \mathrm{NH}_{2}: \mathrm{F}=91.3, \mathrm{p}$-value $<0.001 ; \mathrm{PS}-\mathrm{COOH}: \mathrm{F}=71.5 ; \mathrm{p}$-value $<0.001$; PS-Plain: $\mathrm{F}=51.7, \mathrm{p}$-value $<0.001$ ),

176 the values were buffered in seawater (Figure 1B). For the PS- $\mathrm{NH}_{2}$, in ASW and FSW, a mean

177 reduction of $69 \%$ of the particle surface charge was observed in comparison with UW $(58.0 \pm 2.5$

$178 \mathrm{mV}$ ). For the PS- $\mathrm{COOH}$, the $\zeta$-potential increased by $20 \%$ and $70 \%$ in ASW and FSW, respectively, as

179 compared to UW $(-40.7 \pm 3.4 \mathrm{mV})$. Similarly for the PS-Plain, a significant increase of $11 \%$ was

180 observed in ASW and 34\% in FSW compared to UW (-43.1 $\pm 0.8 \mathrm{mV})$.

\section{$181 \quad 3.2$ Influence of the salinity}

182 No statistical effect (ANOVA, p-value $>0.05$ ) of the ionic strength gradient was observed on the 183 aggregation of $\mathrm{PS}-\mathrm{NH}_{2}$ particles (mean value $=51.2 \pm 1.8 \mathrm{~nm}$ ) (Figure $2 \mathrm{~A}$ ). Despite this observation, 184 the increase of salinity caused a significant reduction (ANOVA, F=35.7, p-value $<0.001$ ) of the $\zeta$ 185 potential with values corresponding to $58.0,39.2,32.8,22.5$ and $27.4 \mathrm{mV}$ at $0,163.25,326.5$, 186489.75 and $653 \mathrm{mM}$, respectively (Figure 2B). 
187 A significant effect on aggregation level of the PS-COOH (ANOVA, $F=74.5, p$-value $<0.001$ ) and PS-

188 Plain (ANOVA, $F=253.5, p$-value $<0.001$ ) suspensions was demonstrated from $489.75 \mathrm{mM}$ and

$189326.5 \mathrm{mM}$, respectively (Figure 2A). The size of the PS-COOH suspension increased 18-fold from

$1900 / 163.25 / 326.5 \mathrm{mM}$ (mean value $=70.8 \pm 25.9 \mathrm{~nm}$ ) to $653 \mathrm{mM}(1,835 \pm 240 \mathrm{~nm})$. Close results were

191 observed for the PS-Plain with a 38-fold increase from 0/163.25 mM (mean value $=53.8 \pm 6.4 \mathrm{~nm}$ )

192 to $653 \mathrm{mM}(2,106 \pm 75 \mathrm{~nm})$. A significant effect in the $\zeta$-potential was observed with an increasing

193 trend along the gradient for both PS-COOH (ANOVA, F= 6.7; $p$-value < 0.001) and PS-Plain (ANOVA,

$194 \mathrm{~F}=15 ; \mathrm{p}$-value < 0.001) from $326.5 \mathrm{mM}$ (Figure 2B). Compared to $0 \mathrm{mM}$ where PS-COOH and PS-

195 Plain had a mean $\zeta$-potential of -43.9 and $-42.2 \mathrm{mV}$, respectively, a maximal increase of $26 \%$ and

$19628 \%$ was observed at the highest ionic strength (PS-COOH: $-32.6 \pm 3.5 \mathrm{mV}$; PS-Plain: $-30.2 \pm 2.1 \mathrm{mV}$ ).

\subsection{Influence of the organic matter}

198 The highest concentration of organic matter $\left(30 \mathrm{mg} \cdot \mathrm{L}^{-1}\right)$ in UW affected significantly (ANOVA, F= $1991426, \mathrm{p}$-value < 0.001; PDI > 0.2) the average size of the PS- $\mathrm{NH}_{2}$ solution leading to the formation of 200 aggregates with a mean size of $99.4 \pm 1.8 \mathrm{~nm}$ while no aggregation was reported for lower levels of 201 organic matter ( 1 and $10 \mathrm{mg} \cdot \mathrm{L}^{-1}$; mean value $=56.1 \pm 1.4 \mathrm{~nm}$ ) (Figure 3). The addition of organic 202 matter decreased significantly (ANOVA, $F=1497$, $p$-value $<0.001$ ) in a dose-response manner the $\zeta$ 203 potential of the PS-NH $\mathrm{N}_{2}$ in UW $\left(1 \mathrm{mg} \cdot \mathrm{L}^{-1}: 46.2 \pm 0.7 \mathrm{mV} ; 10 \mathrm{mg} \cdot \mathrm{L}^{-1}: 40.5 \pm 0.4 \mathrm{mV} ; 30 \mathrm{mg} \cdot \mathrm{L}^{-1}: 24.3 \pm\right.$ $2040.4 \mathrm{mV}$ ) (Figure 4). In contrast, no effect (ANOVA, $p$-value $>0.05$ ) of the organic matter on the PS$205 \mathrm{NH}_{2}$ (average size and $\zeta$-potential) was observed in ASW (Figure 3 \& 4).

206 For other NP (PS-COOH and PS-Plain), their size and surface charge were statistically similar 207 (ANOVA, $p$-value $>0.05$ ) regardless of the organic matter contents. In UW, the PS-COOH and PS208 Plain suspension remained at a nanoscale without aggregation with an average size and a $\zeta-$ 
209 potential of $57.3 \pm 1.5 \mathrm{~nm} /-42.5 \pm 5.0 \mathrm{mV}$ and $51.8 \pm 1.3 \mathrm{~nm} /-43.0 \pm 4.7 \mathrm{mV}$, respectively (Figures 3

$210 \& 4)$. In ASW and regardless of the OM concentrations, aggregation reached 1,777 $\pm 34 \mathrm{~nm}$ for the

211 PS-COOH and 2,082 $\pm 206 \mathrm{~nm}$ for the PS-Plain with a $\zeta$-potential of $-27.9 \pm 1.6 \mathrm{mV}$ and $-35.7 \pm 3.8$

$212 \mathrm{mV}$, respectively.

\section{$213 \quad 3.4 \quad$ Temporal stability}

214 The PS- $\mathrm{NH}_{2}$ remained at a nanometric scale in all media (UW and ASW with or without OM) but

215 formed small homo-aggregates (PDI > 0.2) at T48h in UW $(67.4 \pm 1.6 \mathrm{~nm}$; ANOVA, F= 33.1, p-value < 216 0.01), ASW (71.8 $\pm 1.3 \mathrm{~nm}$; ANOVA, $\mathrm{F}=181.5, \mathrm{p}$-value $<0.001)$ and ASW+OM $(96.6 \pm 1.6 \mathrm{~nm}$; 217 ANOVA, F: 1300, p-value < 0.001) (Figure 5). In UW+OM at T48h, the PS- $\mathrm{NH}_{2}$ did not aggregate and 218 displayed a size of $56.3 \pm 0.3 \mathrm{~nm}$ (ANOVA, $\mathrm{p}$-value $>0.05$ ). Concerning the $\zeta$-potential, no effect was 219 recorded in ASW with or without organic matter (mean value $=23.8 \pm 2.9 \mathrm{mV}$ ) (Figure 6). However, 220 significant decreases in UW (-12\%; ANOVA, $\mathrm{F}=47.9, \mathrm{p}$-value < 0.001) and UW+OM (-13\%; ANOVA, $221 \mathrm{~F}=148.2, \mathrm{p}$-value < 0.001) were observed at T48h (UW: $45.7 \pm 1.3 \mathrm{mV} ; \mathrm{UW}+\mathrm{OM}: 40.4 \pm 0.4 \mathrm{mV}$ ) 222 compared to TO (UW: $51.4 \pm 0.4 \mathrm{mV}$; UW+OM: $46.7 \pm 0.8 \mathrm{mV}$ ).

223 The PS-COOH and PS-Plain suspensions stayed at a nanoscale in UW (+/- OM) despite the apparition 224 of small aggregates (PDI > 0.2) at $48 \mathrm{~h}$ for the PS-COOH in UW $(68.2 \pm 1.7 \mathrm{~nm}$; ANOVA, F= 50.1, $p$ 225 value $<0.001)$ and UW+OM $(77.4 \pm 4.6 \mathrm{~nm}$; ANOVA, F= 38.9, p-value $<0.001)$ and at $24 \mathrm{~h}$ for the PS226 Plain only in UW $(63.3 \pm 5.0 \mathrm{~nm}$; ANOVA, $\mathrm{F}=16.6$, $\mathrm{p}$-value < 0.01) (Figure 5). In both ASW (ANOVA, $227 \mathrm{~F}=42, \mathrm{p}$-value $<0.001$ ) and ASW+OM (ANOVA, $\mathrm{F}=50.6, \mathrm{p}$-value $<0.001$ ), the PS-COOH formed 228 aggregates with an average size close to $2,000 \mathrm{~nm}$ at $24 \mathrm{~h}$ and $4,000 \mathrm{~nm}$ at $48 \mathrm{~h}$ (Figure 5). The size of 229 the PS-Plain's aggregates in ASW was $1,884 \pm 223 \mathrm{~nm}$ but exceeded the size limit of the zetasizer (10 $230 \mu \mathrm{m})$ at $\mathrm{T} 24 \mathrm{~h}$ and $\mathrm{T} 48 \mathrm{~h}$, thus no statistical analysis was performed even if a clear trend is obvious 
231 with bigger aggregates at T24h and T48h compared to T0. In ASW+OM, the PS-Plain formed bigger

232 aggregates (ANOVA, $F=209.7, \mathrm{p}$-value $<0.001)$ at T24h $(8,343 \pm 228.3 \mathrm{~nm})$ compared to T0 $(3,034 \pm$

$233187 \mathrm{~nm})$ and T48h $(4,637 \pm 480 \mathrm{~nm})$. For PS-COOH, the $\zeta$-potential increased significantly in UW

234 (+32\%; ANOVA, F= 23.73, p-value < 0.01) and UW+OM (+27\%; ANOVA, F= 18.04, p-value < 0.01) at

235 T48h compared to T0 (Figure 6). A significant increase of the $\zeta$-potential was observed over the time

236 for the PS-Plain in UW (+55\%; ANOVA, F= 108.9, p-value < 0.001). In UW+OM, no change was

237 observed at T0 $(-24.3 \pm 0.4 \mathrm{mV})$ and T48h $(-29.9 \pm 0.4 \mathrm{mV})$ but a significantly lower value (ANOVA,

$238 \mathrm{~F}=8.1, \mathrm{p}$-value $<0.05)$ was recorded at T24h $(-45 \% ;-48.8 \pm 1.3 \mathrm{mV})$ (Figure 6). From 0 to $48 \mathrm{~h}$, no

239 effect on the $\zeta$-potential (ANOVA, p-value > 0.05) was observed in ASW with or without organic 240 matter for the PS-COOH and PS-Plain (Figure 6).

\section{Discussion}

242 In ultrapure water, all NP displayed a great stability and stayed at a nanometric scale over time

243 because they presented a high positive or negative charge maintaining electrostatic repulsive forces

244 limiting or reducing aggregation processes (El Badawy et al., 2010; Lin et al., 2010). In contrast,

245 modifications of NP features (aggregation and $\zeta$-potential) were observed in the presence of salts.

246 The behavior of the PS- $\mathrm{COOH}$ and PS-Plain suspensions was drastically affected in both artificial and

247 natural seawater through the formation of microscale homo-aggregates. In contrast, the PS- $\mathrm{NH}_{2}$

248 displayed high stability and stayed dispersed. Because particles were tested exactly in the same

249 media, the observed behavior must be related to the surface functionalization as previously

250 reported for other engineered nanomaterials (ENMs) (Liu et al., 2012). Consistent with our study,

251 fast homo-aggregation of plain and carboxylate nano-polystyrene beads (25 and $50 \mathrm{~nm}$ ) in seawater

252 was previously demonstrated with aggregates larger than $1 \mu \mathrm{m}$ (Della Torre et al., 2014; Tallec et 
253 al., 2018; Wegner et al., 2012). This large aggregation could have strong outcomes in aquatic

254 environments because when the size of aggregates exceeds $1 \mu \mathrm{m}$, nanoparticles loss their Brownian 255 behavior in favor of sedimentation processes (Klaine et al., 2008). Results differed from recent 256 studies using carboxylate and plain nanopolystyrene of $100 \mathrm{~nm}$ where no homo-aggregation was 257 observed under an increasing ionic strength (Cai et al., 2018; González-Fernández et al., 2018). This 258 difference can be explained by the specific features of the particles (e.g. size, surface chemistry and 259 heterogeneity) (Alimi et al., 2018). Homo-aggregation in seawater is one of the most frequent 260 behavior observed for nanomaterials (Christian et al., 2008). It is due to interactions between the 261 negative surface charge of NP and cationic elements naturally present in seawater such as calcium 262 or sodium ions (El Badawy et al., 2010). Hence, the $\zeta$-potential of the PS-COOH and PS-Plain became 263 less negative in seawater decreasing the NP stability (Cai et al., 2018; Lin et al., 2010). Indeed, under 264 the presence of salts, attractive forces (including van der Waals forces) and particles sticking 265 efficiency increased according to the Derjaguin-Landau-Verwey-Overbeek (DLVO) model resulting in 266 homo-aggregation (Alimi et al., 2018; Liu et al., 2012). Thus, the difference of salinity between 267 artificial (30 PSU) and natural (32 PSU) seawater can explained the observed variation of 268 aggregation level of the PS-COOH and PS-Plain. The ionic strength increased from ASW to FSW, as 269 well as the screening of the repulsive electrostatic interactions. In the presence of an excess of 270 added salt, the particles diffuse ion double layer reduces and possible specific ions condensation 271 might occur and decrease the particles net surface charge density. Moreover, in natural seawater, 272 other molecules such as extracellular polymeric substances (EPS) produced by bacteria can also 273 intensify aggregation in comparison to an artificial and controlled medium (Summers et al., 2018). 274 Regarding the PS- $\mathrm{NH}_{2}$, its strong stability in all media was presumably due to a positive coating 275 characterized by a low effect of the ionic strength (particles and homo-aggregates stayed at a 
nanometric scale) in comparison to the two other particles tested. Despite a decrease in the $\zeta$ potential when particles are suspended in seawater, it appears sufficiently high to ensure repulsive mechanism. Overall, the nature of the surface groups and the particles interface has a stronger influence than the nature of the core polymer on the particles aggregation (Liu et al., 2012). To thoroughly test this hypothesis, particles of different nature (PE, PP, PS, non-plastic material) presenting the same coating should be compared in controlled experimental solutions.

Humic substances (HA) - used as proxy of dissolved organic matter (DOM) - had negligible effect on the behavior of all particles in comparison to the presence of salts. Usually, organic matter tends to stabilize nanoparticles by increasing steric surface repulsive forces. The presence of cations can overcome and disrupt this stabilization by several mechanisms (e.g. bridging, electrical repulsion compression) promoting aggregation (Zhang et al., 2009). In agreement with our study, divalent cations $\left(\mathrm{Mg}^{2+}\right.$ and $\left.\mathrm{Ca}^{2+}\right)$ triggered homo-aggregation of carbon nanotubes despite the presence of organic matter (reviewed by Christian et al., 2008). Only for the PS-Plain, HA had a stabilizing impact in seawater causing a partial disaggregation over the temporal experiment (between T24h and T48h) presumably due to an increase in the steric repulsion level. In contrast to previous studies using nanomaterials (Baalousha, 2009; Loosli et al., 2013), no shift in the 弓-potential of NP was observed, explaining the negligible effect of the DOM. This fact is possibly linked to the concentration of HA used in the present study. At a concentration of $100 \mathrm{mg} \cdot \mathrm{L}^{-1}, \mathrm{HA}$ caused a shift in the $\zeta$-potential of iron oxide nanoparticles whilst no effect was perceived at $10 \mathrm{mg} \cdot \mathrm{L}^{-1}$ (Baalousha, 2009) which is consistent with our results at the same concentration. In ultrapure water, an adsorption of $\mathrm{HA}$ on the PS- $\mathrm{NH}_{2}$ is hypothesized with a decrease of the $\zeta$-potential along the increasing gradient of HA doses. Indeed, the anionic groups of HA interact easily with the positive surface charge of the PS- $\mathrm{NH}_{2}$. This adsorption reduced the net charge density and resulted in a small 
aggregation at the highest $\mathrm{HA}$ dose, even though the $\mathrm{PS}-\mathrm{NH}_{2}$ mean size distribution always stayed below $100 \mathrm{~nm}$. Overall, DOM have limited effects on NP behavior in our experimental design but a recent study demonstrated that $25 \mathrm{~nm}$ NP can in reverse affect the assembling of DOM with suspected consequences on carbon flux in oceans according to the environmental concentration of NP (Chen et al., 2018).

The temporal analysis demonstrated that NP formed evolving dynamic structure. Indeed, an increase of the homo-aggregation level is reported over time for all NP tested in ASW and ASW+OM. Hence, it is highly plausible that NP will not be find individually in oceans. Owing to the high aggregation level observed here, if NP have a negative surface charge (acquired naturally or after weathering in rivers) as observed in marine environment (Fotopoulou and Karapanagioti, 2012), the risk of an intake in oceans from freshwater appears therefore low. However, certain events can influence the retention of plastic particles in rivers such as flooding leading to a washout and a huge export of plastic debris to marine systems as recently described in rivers around urban area of the United Kingdom (70\% of microplastics were exported by the flooding) (Hurley et al., 2018). Every year, between 1.15 and 2.41 MT of plastic debris go into oceans from rivers (Lebreton et al., 2017). Thus, in future models or experiments, it will be crucial to consider the behavior of NP with a temporal and seasonal aspect as reported with silver nanoparticles (Ellis et al., 2018).

In the context of increasing number of studies using NP to highlight their toxicity on freshwater (Besseling et al., 2014; Cui et al., 2017; Mattsson et al., 2017) and marine (Canesi et al., 2016; Tallec et al., 2018) organisms, this study revealed that it is unavoidable to properly characterize NP behavior in the experimental systems. Indeed, the risk assessment is completely modified if particles stayed individual or formed aggregates in the medium (Lowry et al., 2012). The presence of 
321 aggregates for PS-COOH and PS-Plain in seawater would be part of their lower toxicity observed in

322 Tallec et al. (2018) compared to PS- $\mathrm{NH}_{2}$ for which we showed in the present study strong stability at

323 nanometric scale. Then, because the PS-Plain formed microscale aggregates in seawater but not in

324 freshwater, the low toxicity of the PS-Plain observed in our previous study on oyster planktonic-

325 stages (Tallec et al., 2018) is far from comparable to the severe outcomes in the freshwater

326 crustacean Daphnia galeata (Cui et al., 2017). Likewise, for a given biological model, various results

327 may be observed according to the medium tested. For instance, the toxicity of the PS- $\mathrm{NH}_{2}$ appeared

328 stronger on the survival of the rotifer Brachionus plicatilis in artificial seawater $\left(\mathrm{EC}_{50}=2.75 \pm 0.67\right.$

$\left.329 \mu \mathrm{g} \cdot \mathrm{mL}^{-1}\right)$ than in natural seawater $\left(\mathrm{EC}_{50}=6.62 \pm 0.87 \mu \mathrm{g} \cdot \mathrm{mL}^{-1}\right.$ ) (Manfra et al., 2017). Colloids, organic

330 matter, macromolecules (e.g. EPS, proteins) or compounds released by organisms in the water, at

331 their epithelium interface or inside the organism, are likely to interact with nanoparticles (corona

332 formation) and change their behavior and bio-availability and consequently potential harmful

333 effects (Lowry et al., 2012). Because, this corona can be specific according to the surface

334 functionalization (Lundqvist et al., 2008), an examination of the influence of natural compounds

335 may be one priority for the ecotoxicological community. For instance, changes in the toxicity of

336 various nanomaterials such as polystyrene (Nasser \& Lynch, 2016), titanium dioxide (Yang et al.,

337 2012), silver (Fabrega et al., 2009), multiwalled carbon nanotubes (Edgington et al., 2010) were

338 reported under co-exposures with humic acids or macromolecules.

339 We conclude that the surface functionalization is deemed to be a major parameter determining the

340 fate of $50 \mathrm{~nm}$ NP in our experimental design and potentially in aquatic environments. The data

341 presented here, complemented by previous studies including the recent publication of Cai et al.

342 (2018) with $100 \mathrm{~nm}$ PS-Plain, emphasizes the need for a thorough characterization of NP 343 considering at least size and coating, in relevant environments in order to better design 
344 experiments, understand end-points and define toxicity thresholds for this new threat. More

345 experiments are required to understand effect of other environmental conditions on NP behavior

346 especially the weathering of particles which can affect their properties as previously observed with

347 MP (Rummel et al., 2017). These results provide new experimental data to consider in the 348 assessment of NP fate in future modeling studies.

\section{Acknowledgments}

350 This project was supported by the ANR-Nanoplastics project (ANR-15-CE34-0006). K. Tallec was

351 funded by a French doctoral research grant from the regional council of the région Bretagne (50\%)

352 and Ifremer (50\%). The authors gratefully thank PA. Jaffres and O. Lozach (UMR-CNRS 6521) for 353 their support and expertise with the DLS.

\section{Authors Contributions}

$355 \mathrm{KT}, \mathrm{AH}, \mathrm{IPP}, \mathrm{GB}, \mathrm{CG}-\mathrm{F}$ designed experiments. $\mathrm{KT}, \mathrm{OB}$ conducted experiments. DLS data were 356 analyzed by $\mathrm{KT}$ and $\mathrm{OB}$. Data were interpreted by $\mathrm{OB}, \mathrm{KT}, \mathrm{AH}, \mathrm{IPP}, \mathrm{PS}$ and $\mathrm{GB}$. KT wrote the initial 357 draft in concertation with AH and IPP. All authors read and contributed to the final manuscript.

\section{$\begin{array}{lll}358 & 7 & \text { References }\end{array}$}

359 Alimi, O. S., Farner Budarz, J., Hernandez, L. M., and Tufenkji, N. (2018). Microplastics and 360 Nanoplastics in Aquatic Environments: Aggregation, Deposition, and Enhanced Contaminant 361 Transport. Environ. Sci. Technol. 52, 1704-1724. doi:10.1021/acs.est.7b05559. 
362 Baalousha, M. (2009). Aggregation and disaggregation of iron oxide nanoparticles: Influence of

363 particle concentration, $\mathrm{pH}$ and natural organic matter. Sci. Total Environ. 407, 2093-2101.

364 doi:10.1016/j.scitotenv.2008.11.022.

365 Baalousha, M., Manciulea, A., Cumberland, S., Kendall, K., and Lead, J. R. (2008). Aggregation and 366 surface properties of iron oxide nanoparticles: influence of $\mathrm{pH}$ and natural organic matter. Environ.

367 Toxicol. Chem. 27, 1875. doi:10.1897/07-559.1.

368 Badawy, A. M. El, Luxton, T. P., Silva, R. G., Scheckel, K. G., Suidan, M. T., and Tolaymat, T. M. (2010).

369 Impact of Environmental Conditions ( $\mathrm{pH}$, Ionic Strength, and Electrolyte Type) on the Surface

370 Charge and Aggregation of Silver Nanoparticles Suspensions. Environ. Sci. Technol. 44, 1260-1266.

371 doi:10.1021/es902240k.

372 Besseling, E., Quik, J. T. K., Sun, M., and Koelmans, A. A. (2017). Fate of nano- and microplastic in 373 freshwater systems: A modeling study. Environ. Pollut. 220, 540-548. 374 doi:10.1016/j.envpol.2016.10.001.

375 Besseling, E., Wang, B., Lürling, M., and Koelmans, A. A. (2014). Nanoplastic affects growth of S. 376 obliquus and reproduction of D. magna. Environ. Sci. Technol. 48, 12336-12343. 377 doi:10.1021/es503001d.

378 Cai, L., Hu, L., Shi, H., Ye, J., Zhang, Y., and Kim, H. (2018). Effects of inorganic ions and natural 379 organic matter on the aggregation of nanoplastics. Chemosphere 197, 142-151. 380 doi:10.1016/j.chemosphere.2018.01.052. 
381 Canesi, L., Ciacci, C., Fabbri, R., Balbi, T., Salis, A., Damonte, G., et al. (2016). Interactions of cationic 382 polystyrene nanoparticles with marine bivalve hemocytes in a physiological environment: Role of 383 soluble hemolymph proteins. Environ. Res. 150, 73-81. doi:10.1016/j.envres.2016.05.045.

384 Chekli, L., Phuntsho, S., Roy, M., Lombi, E., Donner, E., and Shon, H. K. (2013). Assessing the 385 aggregation behaviour of iron oxide nanoparticles under relevant environmental conditions using a 386 multi-method approach. Water Res. 47, 4585-4599. doi:10.1016/j.watres.2013.04.029

387 Chen, C. S., Le, C., Chiu, M. H., and Chin, W. C. (2018). The impact of nanoplastics on marine 388 dissolved organic matter assembly. Sci. Total Environ. 634, 316-320. 389 doi:10.1016/j.scitotenv.2018.03.269.

390 Christian, P., Von Der Kammer, F., Baalousha, M., and Hofmann, T. (2008). Nanoparticles: Structure, 391 properties, preparation and behaviour in environmental media. Ecotoxicology 17, 326-343. 392 doi:10.1007/s10646-008-0213-1.

393 Cózar, A., Echevarria, F., Gonzalez-Gordillo, J. I., Irigoien, X., Ubeda, B., Hernandez-Leon, S., et al. 394 (2014). Plastic debris in the open ocean. Proc. Natl. Acad. Sci. 111, 10239-10244. 395 doi:10.1073/pnas.1314705111.

396 Cózar, A., Martí, E., Duarte, C. M., García-de-Lomas, J., van Sebille, E., Ballatore, T. J., et al. (2017). 397 The Arctic Ocean as a dead end for floating plastics in the North Atlantic branch of the 398 Thermohaline Circulation. Sci. Adv. 3, e1600582. doi:10.1126/sciadv.1600582.

399 Cui, R., Kim, S. W., and An, Y.-J. (2017). Polystyrene nanoplastics inhibit reproduction and induce 400 abnormal embryonic development in the freshwater crustacean Daphnia galeata. Sci. Rep. 7, 401 12095. doi:10.1038/s41598-017-12299-2. 
403 Turning microplastics into nanoplastics through digestive fragmentation by Antarctic krill. Nat. Commun. 9, 1001. doi:10.1038/s41467-018-03465-9.

Della Torre, C., Bergami, E., Salvati, A., Faleri, C., Cirino, P., Dawson, K. A., et al. (2014). Accumulation and Embryotoxicity of Polystyrene Nanoparticles at Early Stage of Development of

407 Sea Urchin Embryos Paracentrotus lividus. Environ. Sci. Technol. 48, 12302-12311. 408 doi:10.1021/es502569w.

409 Douglas, S. J., Illum, L., \& Davis, S. S. (1985). Particle size and size distribution of poly (butyl 2410 cyanoacrylate) nanoparticles. II. Influence of stabilizers. Journal of colloid and interface science, 411 103(1), 154-163.

412 Dubey, M. K., Bijwe, J., and Ramakumar, S. S. V (2015). Nano-PTFE: New entrant as a very promising 413 EP additive. Tribol. Int. 87, 121-131. doi:10.1016/j.triboint.2015.01.026.

414 Edgington, A. J., Roberts, A. P., Taylor, L. M., Alloy, M. M., Reppert, J., Rao, A. M., et al. (2010). The 415 influence of natural organic matter on the toxicity of multiwalled carbon nanotubes. Environ. 416 Toxicol. Chem. 29, 2511-2518. doi:10.1002/etc.309.

417 Ellis, L. A., Baalousha, M., Valsami-Jones, E., and Lead, J. R. (2018). Seasonal variability of natural 418 water chemistry affects the fate and behaviour of silver nanoparticles. Chemosphere 191, 616-625. 419 doi:10.1016/j.chemosphere.2017.10.006.

420 Fabrega, J., Fawcett, S. R., Renshaw, J. C., and Lead, J. R. (2009). Silver nanoparticle impact on 421 bacterial growth: Effect of pH, concentration, and organic matter. Environ. Sci. Technol. 43, 7285422 7290. doi:10.1021/es803259g. 
423 Fotopoulou, K. N., and Karapanagioti, H. K. (2012). Surface properties of beached plastic pellets.

424 Mar. Environ. Res. 81, 70-77. doi:10.1016/j.marenvres.2012.08.010.

425 French, R. A., Jacobson, A. R., Kim, B., Isley, S. L., Penn, R. L., and Baveye, P. C. (2009). Influence of 426 Ionic Strength, $\mathrm{pH}$, and Cation Valence on Aggregation Kinetics of Titanium Dioxide Nanoparticles.

427 Environ. Sci. Technol. 43, 1354-1359. doi:10.1021/es802628n.

428 Galloway, T. S., Cole, M., Lewis, C., Atkinson, A., and Allen, J. I. (2017). Interactions of microplastic 429 debris throughout the marine ecosystem. Nat. Ecol. Evol. 1, 116. doi:10.1038/s41559-017-0116.

430 Gigault, J., Halle, A. ter, Baudrimont, M., Pascal, P., Gauffre, F., Phi, T.-L., et al. (2018). Current 431 opinion: What is a nanoplastic? Environ. Pollut. 235, 1030-1034. doi:10.1016/j.envpol.2018.01.024.

432 Gigault, J., Pedrono, B., Maxit, B., and Ter Halle, A. (2016). Marine plastic litter: the unanalyzed 433 nano-fraction. Environ. Sci. Nano 3, 346-350. doi:10.1039/C6EN00008H.

434 González-Fernández, C., Tallec, K., Le Goïc, N., Lambert, C., Soudant, P., Huvet, A., et al. (2018). 435 Cellular responses of Pacific oyster (Crassostrea gigas) gametes exposed in vitro to polystyrene 436 nanoparticles. Chemosphere 208, 764-772. doi:10.1016/j.chemosphere.2018.06.039.

437 Hernandez, L. M., Yousefi, N., and Tufenkji, N. (2017). Are There Nanoplastics in Your Personal Care 438 Products? Environ. Sci. Technol. Lett. 4, 280-285. doi:10.1021/acs.estlett.7b00187.

439 Hüffer, T., Praetorius, A., Wagner, S., von der Kammer, F., and Hofmann, T. (2017). Microplastic 440 Exposure Assessment in Aquatic Environments: Learning from Similarities and Differences to 441 Engineered Nanoparticles. Environ. Sci. Technol. 51, 2499-2507. doi:10.1021/acs.est.6b04054. 
442 Hurley, R., Woodward, J., and Rothwell, J. J. (2018). Microplastic contamination of river beds

443 significantly reduced by catchment-wide flooding. Nat. Geosci. 1-7. doi:10.1038/s41561-018-0080-

4441.

445 Jambeck, J. R., Geyer, R., Wilcox, C., Siegler, T. R., Perryman, M., Andrady, A., et al. (2015). Plastic

446 waste inputs from land into the ocean. Science 347, 768-771. doi:10.1126/science.1260352.

447 Jeong, C. B., Won, E. J., Kang, H. M., Lee, M. C., Hwang, D. S., Hwang, U. K., et al. (2016).

448 Microplastic Size-Dependent Toxicity, Oxidative Stress Induction, and p-JNK and p-p38 Activation in

449 the Monogonont Rotifer (Brachionus koreanus). Environ. Sci. Technol. 50, 8849-8857. 450 doi:10.1021/acs.est.6b01441.

451 Keller, A. A., Wang, H., Zhou, D., Lenihan, H. S., Cherr, G., Cardinale, B. J., et al. (2010). Stability and 452 Aggregation of Metal Oxide Nanoparticles in Natural Aqueous Matrices. Environ. Sci. Technol. 44, 453 1962-1967. doi:10.1021/es902987d.

454 Klaine, S. J., Alvarez, P. J. J., Batley, G. E., Fernandes, T. F., Handy, R. D., Lyon, D. Y., et al. (2008). 455 Nanomaterials in the environment: Behavior, fate, bioavailability, and effects. Environ. Toxicol. 456 Chem. 27, 1825. doi:10.1897/08-090.1.

457 Koelmans, A. A., Besseling, E., Foekema, E., Kooi, M., Mintenig, S., Ossendorp, B. C., et al. (2017). 458 Risks of Plastic Debris: Unravelling Fact, Opinion, Perception, and Belief. Environ. Sci. Technol., 459 acs.est.7b02219. doi:10.1021/acs.est.7b02219.

460 Koelmans, A. A., Bakir, A., Burton, G. A., and Janssen, C. R. (2016). Microplastic as a Vector for 461 Chemicals in the Aquatic Environment: Critical Review and Model-Supported Reinterpretation of 462 Empirical Studies. Environ. Sci. Technol. 50, 3315-3326. doi:10.1021/acs.est.5b06069. 
463 Koelmans, A. A., Besseling, E., and Shim, W. J. (2015). "Nanoplastics in the Aquatic Environment.

464 Critical Review," in Marine Anthropogenic Litter (Cham: Springer International Publishing), 325-340.

465 doi:10.1007/978-3-319-16510-3_12.

466 Lambert, S., and Wagner, M. (2016). Characterisation of nanoplastics during the degradation of 467 polystyrene. Chemosphere 145, 265-268. doi:10.1016/j.chemosphere.2015.11.078.

468 Lebreton, L. C. M., van der Zwet, J., Damsteeg, J.-W., Slat, B., Andrady, A., and Reisser, J. (2017).

469 River plastic emissions to the world's oceans. Nat. Commun. 8, 15611. doi:10.1038/ncomms15611.

470 Lin, D., Tian, X., Wu, F., and Xing, B. (2010). Fate and Transport of Engineered Nanomaterials in the

471 Environment. J. Environ. Qual. 39, 1896. doi:10.2134/jeq2009.0423.

472 Liu, J., Legros, S., Ma, G., Veinot, J. G. C., Kammer, F. Von Der, and Hofmann, T. (2012). Influence of 473 surface functionalization and particle size on the aggregation kinetics of engineered nanoparticles.

474 Chemosphere 87, 918-924. doi:10.1016/j.chemosphere.2012.01.045.

475 Liu, J., Ma, Y., Zhu, D., Xia, T., Qi, Y., Yao, Y., et al. (2018). Polystyrene Nanoplastics-Enhanced 476 Contaminant Transport: Role of Irreversible Adsorption in Glassy Polymeric Domain. Environ. Sci. 477 Technol. 52, 2677-2685. doi:10.1021/acs.est.7b05211.

478 Loosli, F., Le Coustumer, P., and Stoll, S. (2013). $\mathrm{TiO}_{2}$ nanoparticles aggregation and disaggregation 479 in presence of alginate and Suwannee River humic acids. $\mathrm{pH}$ and concentration effects on 480 nanoparticle stability. Water Res. 47, 6052-6063. doi:10.1016/j.watres.2013.07.021. 
481 Loucaide, S., Cappelle, P., Van, Behrends, T., 2008. Dissolution of biogenic silica from land to ocean: 482 Role of salinity and pH. Limnol. Oceanogr. 53, 1614-1621. 483 https://doi.org/10.4319/lo.2008.53.4.1614

484 Lowry, G. V., Gregory, K. B., Apte, S. C., and Lead, J. R. (2012). Transformations of Nanomaterials in 485 the Environment. Environ. Sci. Technol. 46, 6893-6899. doi:10.1021/es300839e.

486 Lundqvist, M., Stigler, J., Elia, G., Lynch, I., Cedervall, T., and Dawson, K. A (2008). Nanoparticle size 487 and surface properties determine the protein corona with possible implications for biological 488 impacts. Proc. Natl. Acad. Sci. 105, 14265-14270. doi:10.1073/pnas.0805135105.

489 Lusher, A. L., Peter, H., and Mendoza-Hill, J. (2017). Microplastics in fisheries and aquaculture. FAO 490 Fisheries and Aquaculture Technical Paper (FAO) eng no. 615.

491 Manfra, L., Rotini, A., Bergami, E., Grassi, G., Faleri, C., and Corsi, I. (2017). Comparative ecotoxicity 492 of polystyrene nanoparticles in natural seawater and reconstituted seawater using the rotifer 493 Brachionus plicatilis. Ecotoxicol. Environ. Saf. 145, 557-563. doi:10.1016/j.ecoenv.2017.07.068.

494 Mattsson, K., Hansson, L.-A., and Cedervall, T. (2015). Nano-plastics in the aquatic environment. 495 Environ. Sci. Process. Impacts 17, 1712-1721. doi:10.1039/C5EM00227C.

496 Mattsson, K., Johnson, E. V., Malmendal, A., Linse, S., Hansson, L.-A., and Cedervall, T. (2017). Brain 497 damage and behavioural disorders in fish induced by plastic nanoparticles delivered through the 498 food chain. Sci. Rep. 7, 11452. doi:10.1038/s41598-017-10813-0. 
499 Mintenig, S. M., Bäuerlein, P. S., Koelmans, A. A., Dekker, S. C., and Van Wezel, A. P. (2018). Closing 500 the gap between small and smaller: towards a framework to analyse nano- and microplastics in 501 aqueous environmental samples. Environ. Sci. Nano 5, 1640-1649. doi:10.1039/c8en00186c.

502 Mohd Omar, F., Abdul Aziz, H., and Stoll, S. (2014). Aggregation and disaggregation of ZnO 503 nanoparticles: Influence of $\mathrm{pH}$ and adsorption of Suwannee River humic acid. Sci. Total Environ. 504 468-469, 195-201. doi:10.1016/j.scitotenv.2013.08.044.

505 Nasser, F., Lynch, I., 2016. Secreted protein eco-corona mediates uptake and impacts of polystyrene 506 nanoparticles on Daphnia magna. J. Proteomics 137, 45-51. 507 https://doi.org/10.1016/j.jprot.2015.09.005

508 Paul-Pont, I., Tallec, K., Gonzalez-Fernandez, C., Lambert, C., Vincent, D., Mazurais, D., et al. (2018). 509 Constraints and Priorities for Conducting Experimental Exposures of Marine Organisms to 510 Microplastics. Front. Mar. Sci. 5, 1-22. doi:10.3389/fmars.2018.00252.

511 PlasticsEurope (2017). Plastics - The Facts 2017: An Analysis of European Latest Plastics Production, 512 Demand and Waste Data.

513 R Core Team (2016). R: A language and environment for statistical computing. R Foundation for 514 Statistical Computing, Vienna, Austria. URL https://www.R-project.org/.

515 Rochman, C. M. (2018). Microplastics research-from sink to source. Science 360, 28-29. 516 doi:10.1126/science.aar7734.

517 Rossi, G., Barnoud, J., and Monticelli, L. (2014). Polystyrene nanoparticles perturb lipid membranes. 518 J. Phys. Chem. Lett. 5, 241-246. doi:10.1021/jz402234c. 
519 Rummel, C. D., Jahnke, J., Gorokhova, E., Kühnel, D., and Schmitt-Jansen M. (2017). Impacts of

520 Biofilm Formation on the Fate and Potential Effects of Microplastic in the Aquatic Environment.

521 Environ. Sci. Technol. Lett. 4, 258-267. doi:10.1021/acs.estlett.7b00164.

522 Stephens, B., Azimi, P., El Orch, Z., and Ramos, T. (2013). Ultrafine particle emissions from desktop

523 3D printers. Atmos. Environ. 79, 334-339. doi:10.1016/j.atmosenv.2013.06.050.

524 Summers, S., Henry, T., and Gutierrez, T. (2018). Agglomeration of nano- and microplastic particles

525 in seawater by autochthonous and de novo-produced sources of exopolymeric substances. Mar.

526 Pollut. Bull. 130, 258-267. doi:10.1016/j.marpolbul.2018.03.039.

527 Tallec, K., Huvet, A., Di Poi, C., González-Fernández, C., Lambert, C., Petton, B., et al. (2018).

528 Nanoplastics impaired oyster free living stages, gametes and embryos. Environ. Pollut. 242, 1226-

529 1235. doi:10.1016/j.envpol.2018.08.020.

530 Ter Halle, A., Jeanneau, L., Martignac, M., Jardé, E., Pedrono, B., Brach, L., et al. (2017). Nanoplastic

531 in the North Atlantic Subtropical Gyre. Environ. Sci. Technol. 51, 13689-13697.

532 doi:10.1021/acs.est.7b03667.

533 Velzeboer, I., Kwadijk, C. J. A. F., and Koelmans, A. A. (2014). Strong Sorption of PCBs to 534 Nanoplastics, Microplastics, Carbon Nanotubes, and Fullerenes. Environ. Sci. Technol. 48, 4869535 4876. doi:10.1021/es405721v.

536 Wagner, M., Scherer, C., Alvarez-Muñoz, D., Brennholt, N., Bourrain, X., Buchinger, S., et al. (2014).

537 Microplastics in freshwater ecosystems: what we know and what we need to know. Environ. Sci.

538 Eur. 26, 12. doi:10.1186/s12302-014-0012-7. 
539 Wegner, A., Besseling, E., Foekema, E. M., Kamermans, P., and Koelmans, A. A. (2012). Effects of

540 nanopolystyrene on the feeding behavior of the blue mussel (Mytilus edulis L.). Environ. Toxicol.

541 Chem. 31, 2490-2497. doi:10.1002/etc.1984.

542 Woodall, L. C., Sanchez-Vidal, A., Canals, M., Paterson, G. L. J., Coppock, R., Sleight, V., et al. (2014).

543 The deep sea is a major sink for microplastic debris. R. Soc. Open Sci. 1, 140317-140317.

544 doi:10.1098/rsos.140317.

545 Wright, S. L., and Kelly, F. J. (2017). Plastic and Human Health: A Micro Issue? Environ. Sci. Technol.

546 51, 6634-6647. doi:10.1021/acs.est.7b00423.

547 Yang, S. P., Bar-llan, O., Peterson, R. E., Heideman, W., Hamers, R. J., and Pedersen, J. A. (2013).

548 Influence of Humic Acid on Titanium Dioxide Nanoparticle Toxicity to Developing Zebrafish. Environ.

549 Sci. Technol. 47, 4718-4725. doi:10.1021/es3047334.

550 Zhang, H., Kuo, Y. Y., Gerecke, A. C., and Wang, J. (2012). Co-release of hexabromocyclododecane

551 ( $\mathrm{HBCD}$ ) and nano- and microparticles from thermal cutting of polystyrene foams. Environ. Sci.

552 Technol. 46, 10990-10996. doi:10.1021/es302559v.

553 Zhang, Y., Chen, Y., Westerhoff, P., and Crittenden, J. (2009). Impact of natural organic matter and

554 divalent cations on the stability of aqueous nanoparticles. Water Res. 43, 4249-4257.

555 doi:10.1016/j.watres.2009.06.005.

5568 Figure Legend

557 Figure 1. Size average $(\mathrm{nm} ; \mathrm{A})$ and $\zeta$-potential $(\mathrm{mV} ; \mathrm{B})$ of three $50 \mathrm{~nm}$ nanoplastics (PS-NH ${ }_{2}$; PS$558 \mathrm{COOH}$; PS-Plain) in three media: ultrapure water (UW; white), artificial seawater (ASW; light grey) 559 and $2-\mu \mathrm{m}$ filtered natural seawater (FSW; dark grey). DLS analysis were replicated 3 times and data 
560 are given as mean \pm SD. Multiple pairwise comparisons were performed using the Tukey's HSD

561 method; homogeneous groups share the same letter.

562 Figure 2. Average size $(\mathrm{nm} ; \mathrm{A})$ and $\zeta$-potential $(\mathrm{mV} ; \mathrm{B})$ of three $50 \mathrm{~nm}$ nanoplastics (PS-NH $\mathrm{N}_{2}$ PS$563 \mathrm{COOH}$; PS-Plain) along a salinity gradient $(0,163.25,326.5,489.75,653 \mathrm{mM})$. DLS analysis were 564 replicated 3 times and data are given as mean \pm SD. Multiple pairwise comparisons were performed 565 using the Tukey's HSD method; homogeneous groups share the same letter.

566 Figure 3. Average size $(\mathrm{nm})$ of three $50 \mathrm{~nm}$ nanoplastics (PS-NH $\mathrm{NH}_{2}$ PS-COOH; PS-Plain) in two media 567 (ultapure water - UW or artificial seawater - ASW) with three different doses of organic matter: 1 568 (white), 10 (light grey) and 30 (black) mg. L $^{-1}$. DLS analysis were replicated 3 times and data are given 569 as mean \pm SD. Multiple pairwise comparisons were performed using the Tukey's HSD method; 570 homogeneous groups share the same letter.

571 Figure 4. $\zeta$-potential $(\mathrm{mV})$ of three $50 \mathrm{~nm}$ nanoplastics (PS- $\mathrm{NH}_{2} ; \mathrm{PS}-\mathrm{COOH}$; PS-Plain) in two media 572 (ultapure water - UW or artificial seawater - ASW) according to three different doses of organic 573 matter: 1 (white), 10 (light grey) and 30 (black) mg. L $^{-1}$. DLS analysis were replicated 3 times and data 574 are given as mean \pm SD. Multiple pairwise comparisons were performed using the Tukey's HSD 575 method; homogeneous groups share the same letter.

576 Figure 5. Average size $(\mathrm{nm})$ of three $50 \mathrm{~nm}$ nanoplastics (PS- $\mathrm{NH}_{2}$; PS-COOH; PS-Plain) over time (T0, 577 T24h and T48h) in two media (ultapure water - UW and artificial seawater - ASW) with or without 578 organic matter (OM, $\left.10 \mathrm{mg} \cdot \mathrm{L}^{-1}\right)$. DLS analysis were replicated 3 times and data are given as mean \pm 579 SD. Multiple pairwise comparisons were performed using the Tukey's HSD method; homogeneous 580 groups share the same letter.

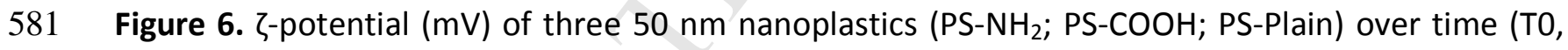
582 T24h and T48h) in two media (ultapure water - UW and artificial seawater - ASW) with or without 583 organic matter (OM, $\left.10 \mathrm{mg} \cdot \mathrm{L}^{-1}\right)$. DLS analysis were replicated 3 times and data are given as mean \pm 584 SD. Multiple pairwise comparisons were performed using the Tukey's HSD method; homogeneous 585 groups share the same letter. 


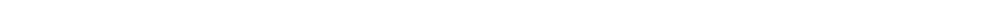

B

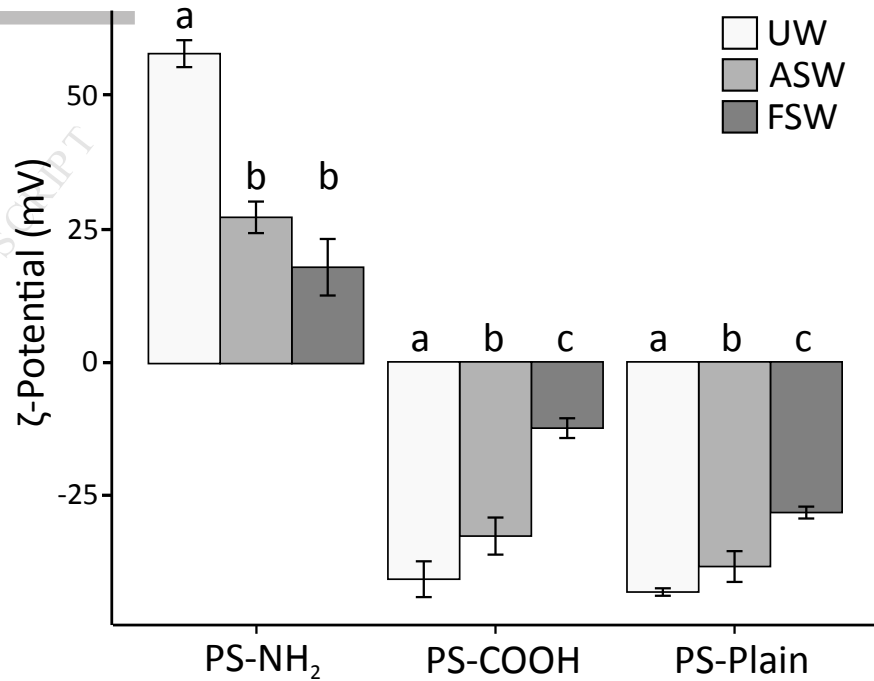



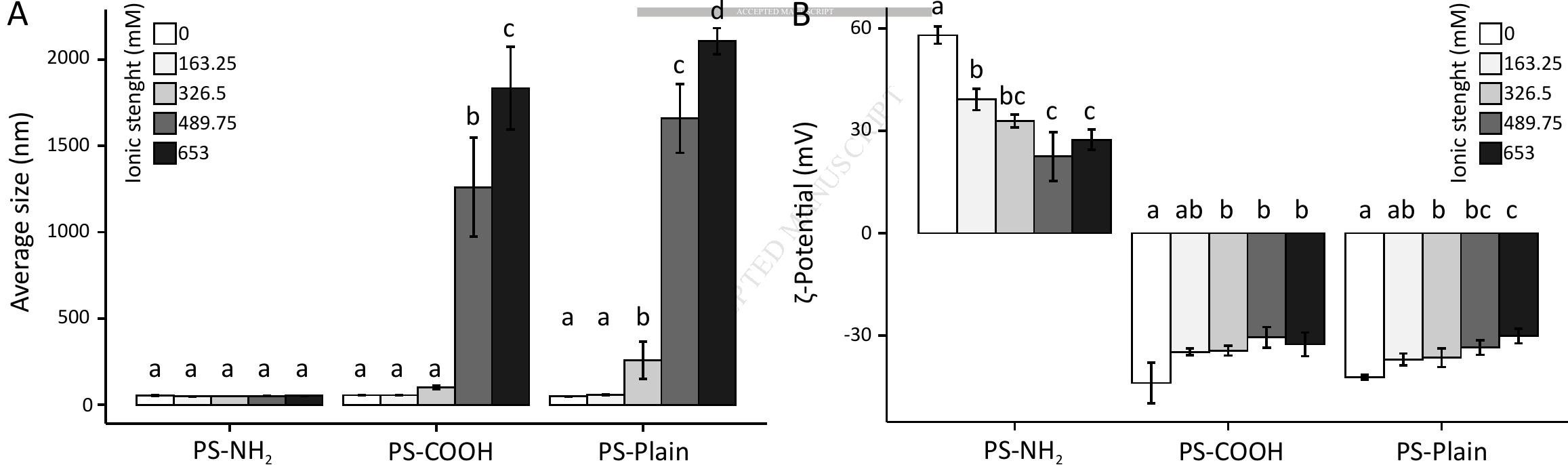


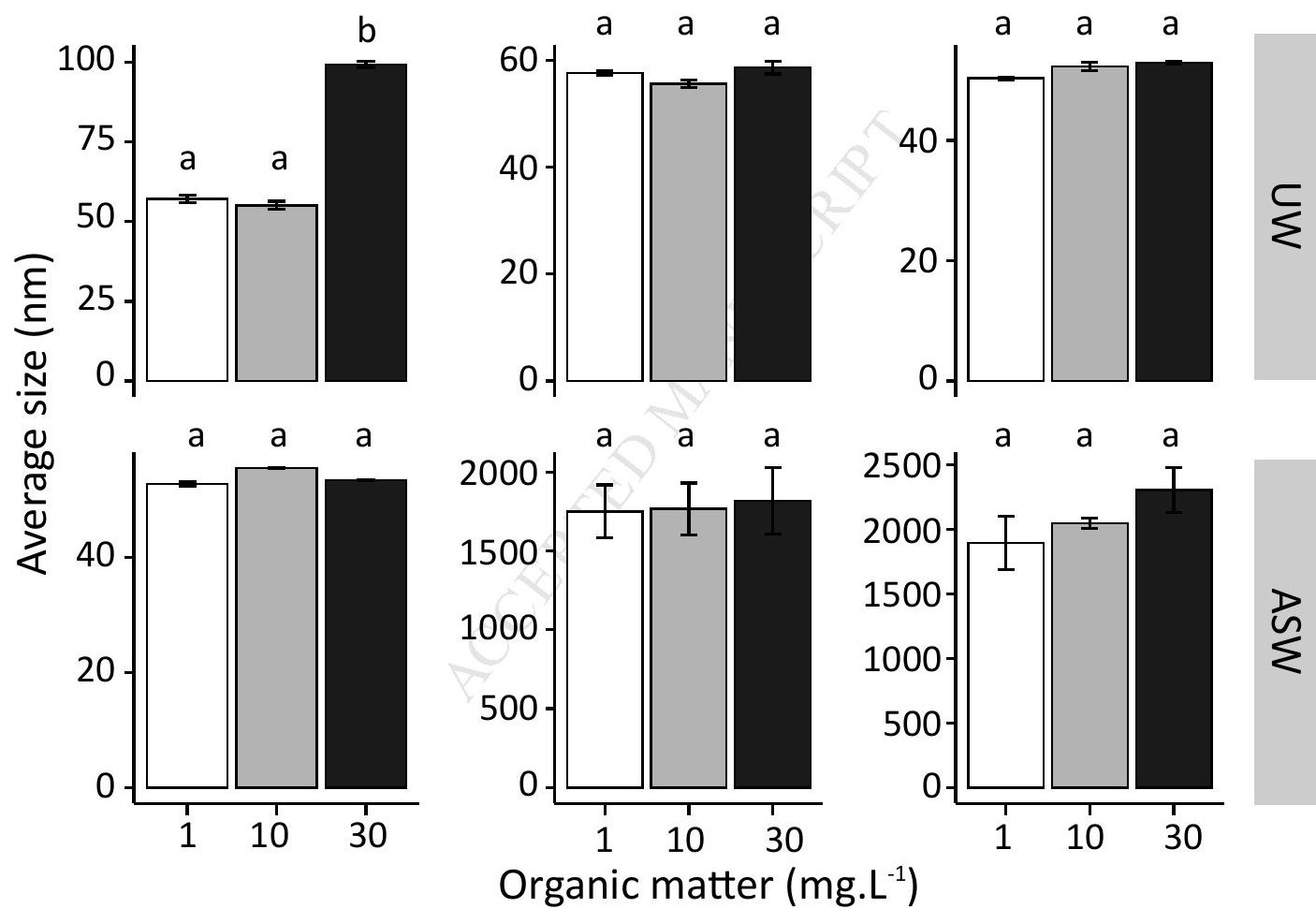




\section{PS- $\mathrm{NH}_{2}$ PS-COOH PS-Plain}

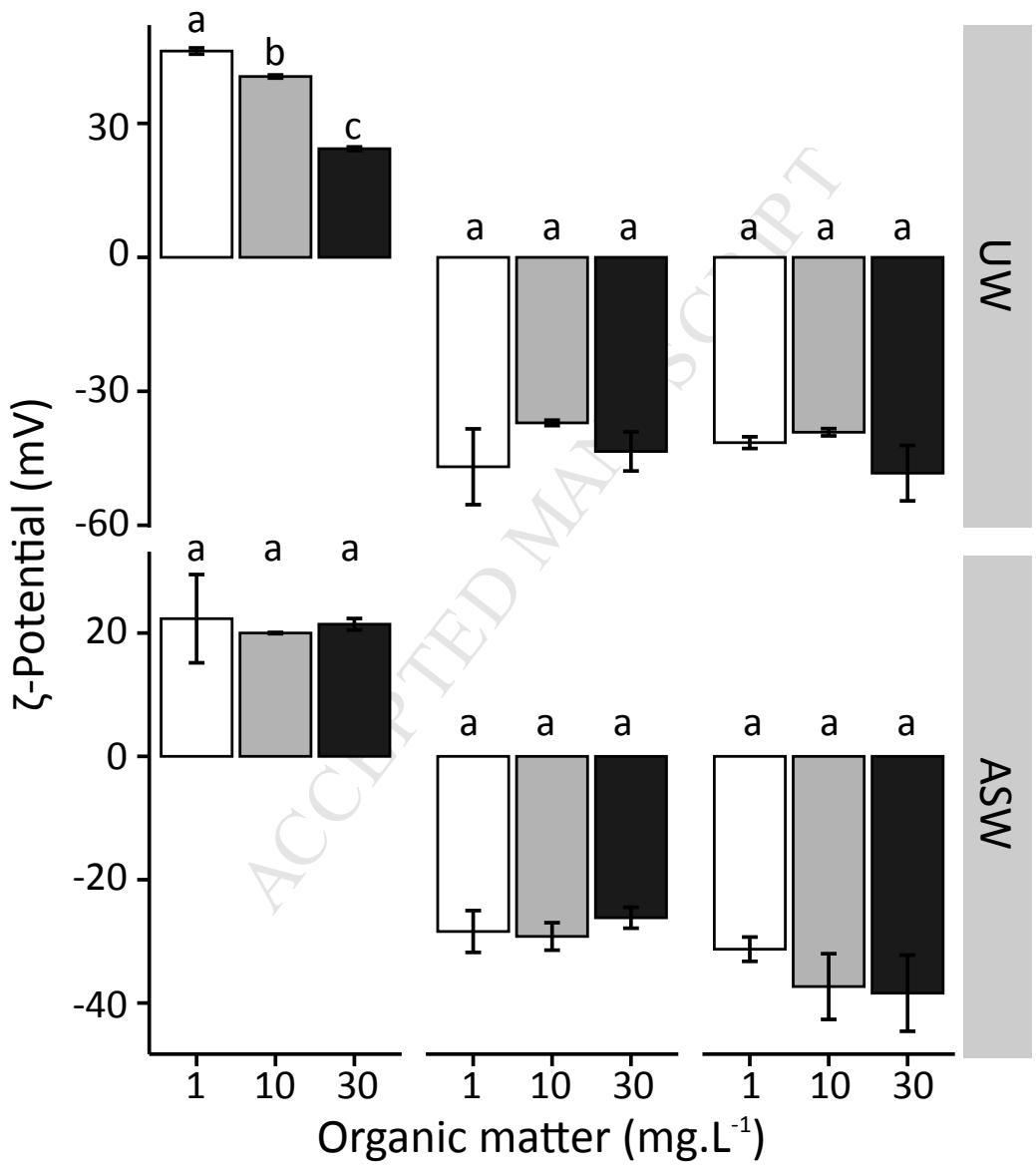



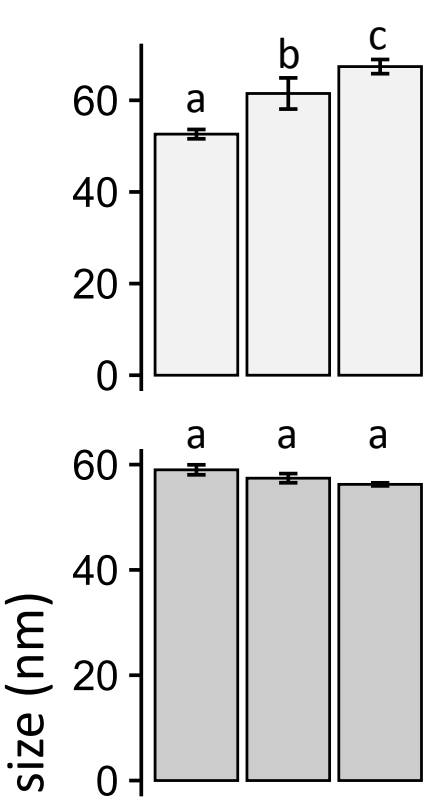

\begin{tabular}{l}
0 \\
0 \\
0 \\
$\frac{1}{2}$ \\
0 \\
\hline
\end{tabular}
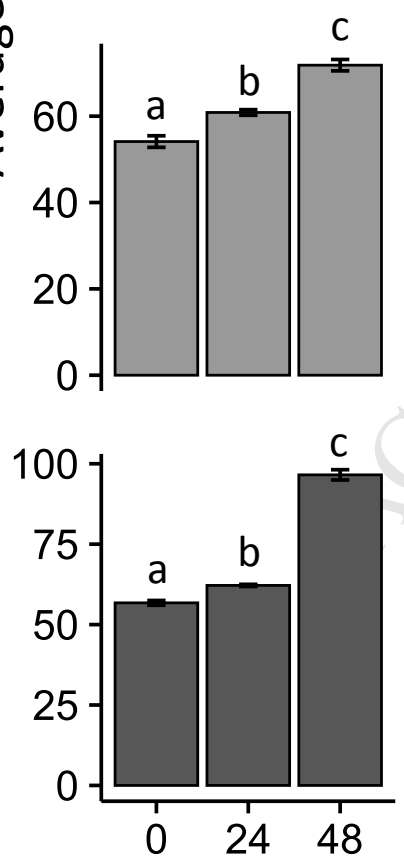
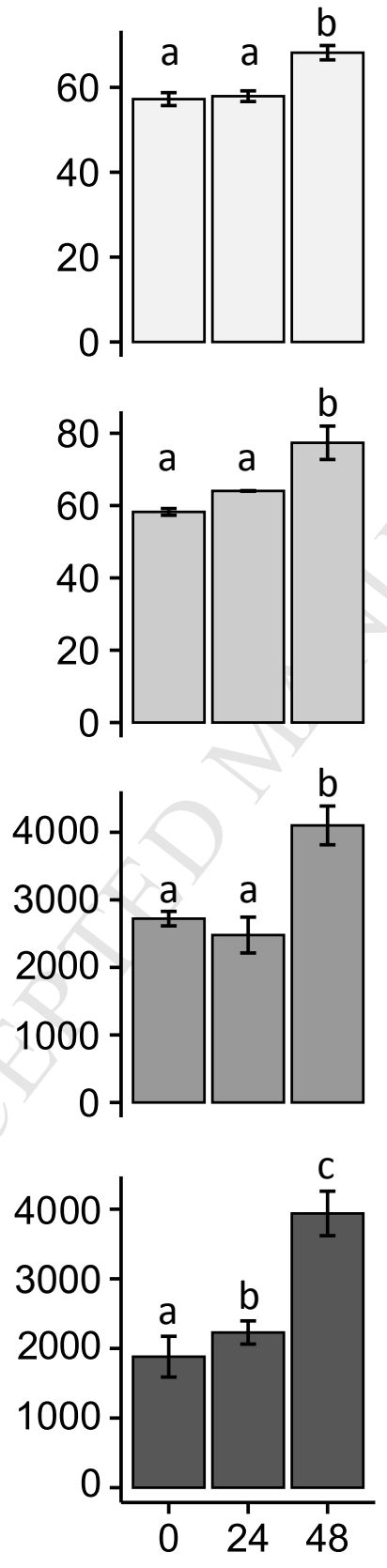

Time (h)
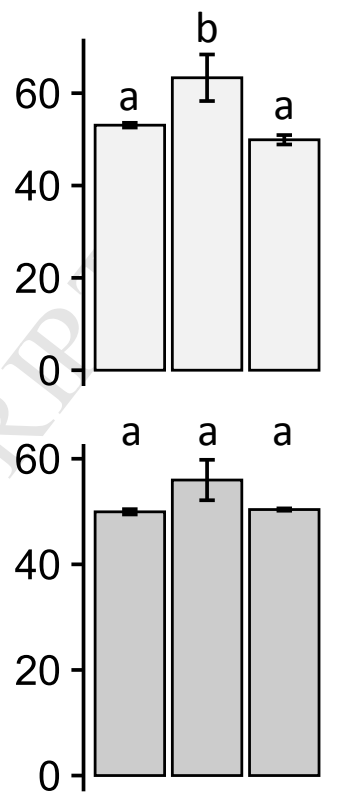

$c$
$\sum$
$\vdots$
$\vdots$
3

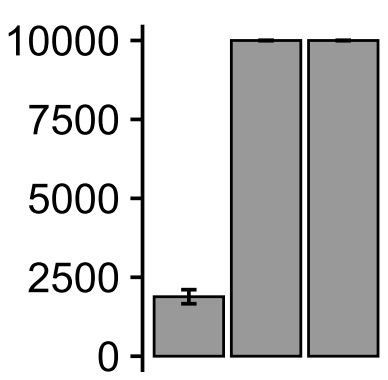

$\sum^{D}$

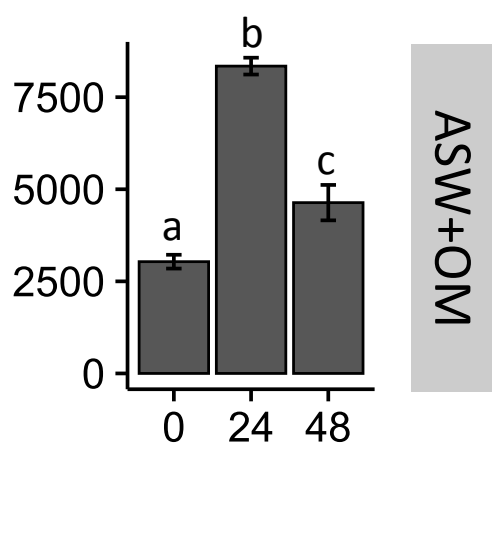




\section{PS-NH ${ }_{2} \quad$ PS-COOH PS-Plain}
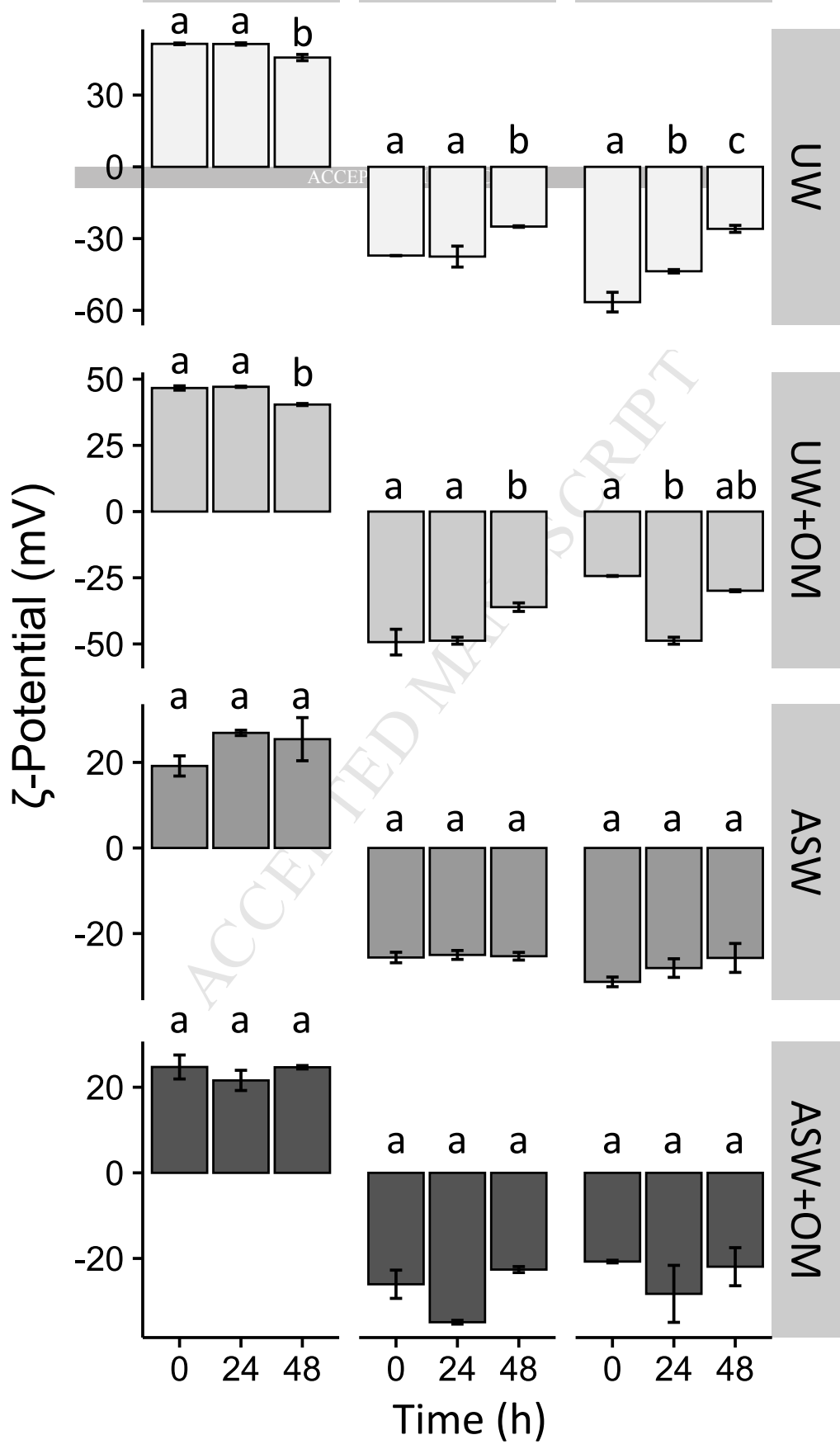